Review

\title{
Can Botulinum Toxin A Play a Role in Treatment of Chronic Pelvic Pain Syndrome in Female Patients?-Clinical and Animal Evidence
}

\author{
Chin-Li Chen and En Meng * \\ Division of Urology, Department of Surgery, Tri-Service General Hospital, National Defense Medical Center, 325, \\ Section 2, Cheng-Gung Road, Taipei 114, Taiwan; j0921713355@gmail.com \\ * Correspondence: en.meng@gmail.com; Tel.: +886-2-87927169
}

Received: 31 December 2019; Accepted: 7 February 2020; Published: 10 February 2020

\begin{abstract}
Chronic pelvic pain (CPP) is defined as chronic pain and inflammation in the pelvic organs for more than six months. There are wide ranges of clinical presentations, including pelvic pain, painful intercourse, irritable bowel syndrome, and pain during urinating. Chronic pelvic pain syndrome (CPPS) is a subdivision of CPP, and the pain syndrome may be focused within a single organ or more than one pelvic organ. As there is uncertain pathogenesis, no standard treatment is currently available for CPPS. Botulinum toxin A (BoNT-A) is a potent neurotoxin that blocks acetylcholine release to paralyze muscles. Intravesical BoNT-A injection can reduce bladder pain in patients with interstitial cystitis/bladder pain syndrome. BoNT-A injected into the pelvic floor muscles of women has also been reported to improve chronic pain syndrome. Due to the reversible effect of BoNT-A, repeated injection appears to be necessary and effective in reducing symptoms. Adverse effects of BoNT-A may worsen the preexisting conditions, including constipation, stress urinary incontinence, and fecal incontinence. This review summarizes the evidence of BoNT-A treatment for CPPS in animal studies and clinical studies regarding the therapeutic effects of BoNT-A for CPPS in female patients.
\end{abstract}

Keywords: botulinum toxin A; chronic pelvic pain syndrome; pelvic pain

Key Contribution: We have reviewed the current basic and clinical evidence of BoNT-A injections for treating CPPS in female patients. This treatment is safe and effective and should be considered as a standard treatment for female CPPS.

\section{Introduction}

Chronic pelvic pain (CPP) is chronic or persistent pain perceived in pelvic structures for more than six months with continuous or recurrent pelvic pain as well as with symptoms suggestive of the lower urinary tract, sexual, bowel, pelvic floor or gynecological dysfunction in men and women [1]. CPP may be divided into situations with well-defined classical pathology (such as infection or cancer) and those without confirmed etiology [1]. According to this classification, the former is considered to be "specific disease-associated pelvic pain," and the latter is described as "chronic pelvic pain syndrome" (CPPS) [1]. The incidence rate of CPP in women is around $6 \%$ to $27 \%$ worldwide [2]. CPP in women is reported to affect 18-50-year-old women, mostly [3].

CPPS is a subdivision of CPP and the pain syndrome may be focused within a single organ or more than one pelvic organ, including bladder, urethra, vagina, rectum, anus and whole pelvic musculatures [1]. When the pain is localized to a single organ, some specialists use an end organ term such as Bladder Pain Syndrome (BPS), and use "syndrome" to indicate pain localized in more than one 
organ site [1]. However, some specialists sub-divide pelvic pain through psychological and functional symptoms rather than anatomy [1].

CPPS of women can exhibit different symptoms, including dyspareunia, dysmenorrhea, dyschezia, and non-menstrual pelvic pain. It may also cause lower urinary tract symptoms, such as frequency, urgency, difficulty urinating, and pain with urination. The most important evaluations for diagnosis of CPPS are medical history and physical examinations. [4]. Vaginal examination is critical to diagnose pelvic floor spasm due to the easily palpable taut muscles. Electromyography, perineometry, vaginal manometry, and digital assessment of pelvic floor muscle (PFM) are also conducted for diagnosis [5]. There are limited laboratory testing and imaging for diagnosis, and it should be considered to be evaluated by laparoscopic or urologic evaluation according to the clinical findings [4].

There is no single definitive etiology or standard management for CPPS. It is supposed that CPPS results from a combination of risk factors, such as neurological, mechanical, and biochemical factors. More than one-half of CPP patients live with interstitial cystitis/painful bladder syndrome (IC/BPS), endometriosis, irritable bowel syndrome, or pelvic adhesions [6,7]. Spasticity of the PFMs, which leads to an increase in muscle tone, has been proposed to play one of the important pathogenic factors of CPPS [8]. PFMs spasm may result from a primary event on the pelvic floor musculatures or secondary to other diseases related to psychological or pathological disorders. It is another significant problem that may decrease quality of life and increase health care costs.

The European Association of Urology (EAU) proposed comprehensive guidelines about the diagnosis and management of CPPS [1]. Management for CPPS remains limited, and the treatment points are usually symptom relief [9]. Secondary disease processes associated with CPPS in women should receive targeted treatment first. The etiologies of CPPS involve multiple mechanisms, so treatments for CPPS need a holistic approach including behavioral, physical, psychological, and sexual components. Modalities of treatments for CPP involve behavioral interventions, physical therapy, medications, surgical interventions, and alternative therapies [4]. The EAU guidelines suggest simple analgesics, such as nonsteroidal anti-inflammatory drugs, to be the first-line therapy of general management. Opioids and neuropathic analgesics, such as tricyclic antidepressants, anticonvulsants, and gabapentin, should be used as further medications if simple analgesics fail. If medications fail to provide symptom relief, nonpharmacologic managements, such as nerve blocks, suprapubic transcutaneous electrical nerve stimulation, sacral neuromodulation, and injection with Botulinum toxin A (BoNT-A) should be considered to help treat CPPS.

Botulinum neurotoxin (BoNT) comprises seven different serotypes (A to G) and more than 40 subtypes [10]. These serotypes have a similar mechanism to inhibit the release of acetylcholine (ACh), but they have different potency of actions. Among different subtypes of BoNT-A, A1 is the only isoform for the therapeutic purpose because of the high potency and long duration of paralysis [11]. The only subtypes of BoNT for clinical purposes are A1 and B1 [12]. However, the paralytic effect of BoNT-B is not as efficient as the function of BoNT-A according to the results of Sloop et al. [13]. The most studied BoNT for clinical treatment is BoNT-A.

BoNT-A injection can reduce spasms and pressure in the PFMs of women with CPPS [14]. Many women with CPPS reported diminution of pelvic pain symptoms after BoNT-A injection. Reduction in pelvic pain can improve quality of life, social activity, working performance, sexual relationships, urinating pain, and mood situations [15]. BoNT-A injected into the pelvic floor musculature of women with CPPS has been reported to improve chronic pelvic pain symptoms and spasms of PFMs [14]. The organ specificity of pelvic pain syndrome in CPPS includes urology, gynecology, gastroenterology, neurology, sexology, and the pelvic floor [1]. This review will focus on the BoNT-A treatment in female CPPS, especially in PFMs pain, IC/BPS, and sexual pain syndrome.

\section{Mechanisms of BoNT-A for Treating CPPS}

Bacterium Clostridium botulinum was first isolated in 1895. BoNT-A was first purified from bacterium Clostridium botulinum in 1928 and its off-label use started in the 70s [16]. 
There are three major mechanisms of BoNT-A that function on the muscles, neural system, and inflammation to relieve pain symptoms [17]. BoNT-A plays an important function in the reduction of pain symptoms. It is believed that spasms and tenderness of the PFMs are highly associated with CPPS in women $[18,19]$. BoNT-A injection has been used to paralyze muscles, and its effect is localized, partial, and reversible. After injecting to the PFMs, BoNT-A can reduce the hypertonic pressure and improve pelvic muscle spasms.

BoNT-A is a selective neurotoxin that acts on neuromusculatures. After binding to terminal receptors on the motor neuron, it can inhibit the release of ACh to cause muscle paralysis. BoNT-A inhibits ACh vesicles releasing to the synaptic cleft by cleaving particular proteins, such as SNAP-25 or VAMP, which are essential for binding with ACh vesicles at the presynaptic membrane. Due to the effect of BoNT-A, there is no release of ACh in the synaptic cleft, and it can paralyze the innervated muscles subsequently [20]. This mechanism has been used to relieve the storage of lower urinary tract symptoms of IC/BPS such as frequency and urgency.

Animal studies reported that BoNT-A could inhibit the delivery of several neurotransmitters, such as calcitonin gene-related peptide (CGRP), glutamate, adenosine triphosphate (ATP), and substance $\mathrm{P}$ [21-25].

BoNT-A may block these neurotransmitters from releasing muscular nociceptors, and reduce the symptom of muscle pain in patients with CPPS [26]. BoNT-A could also inhibit the contraction of muscles via alpha and gamma motor neurons and block spasms of pelvic floor musculature, which results in relieving the pelvic pain caused by muscle spasms [26]. Current literature has shown that the use of BoNT-A can reduce the hypertonicity of PFMs to improve pain scores from CPPS patients.

In addition, BoNT-A has the analgesic effect of relieving pain symptoms. From the animal and human studies, increased expression of cell membranes receptors, such as the TRPV1 and P2 $\times 3$, in the nociceptors may up-regulate the symptoms of neuralgia [27,28]. BoNT-A has been reported to reduce the expression of TRPV1 in rats with neuropathic pain [29].

After the injection of BoNT-A, paralysis of muscle occurs after 2-5 days [5]. The functional effects can typically last from three to six months [14]. The clinical efficacy of BoNT-A injection for CPPS in women was durable to 24 weeks [30]. This long-term but reversible effect has made BoNT-A an important therapy for a wide variety of neuromuscular diseases.

After formation of antibodies against BoNT-A, the duration of the BoNT-A effect and the therapeutic extent of the maximal treatment effect are usually reduced after a few BoNT-A applications (partial therapy failure) before complete therapy failure occurs [5].

\section{Clinical Evidence of BoNT-A for Pelvic Floor Muscle Pain in CPPS Women}

BoNT-A was first used for therapeutic purposes in the 1960s when Dr. Alan B. Scott, an ophthalmologist, injected BoNT-A into extraocular muscles of rhesus monkies to treat strabismus. His results were successfully replicated in humans [31]. BoNT-A has been widely studied in several therapeutic applications and different diseases. However, previous studies and clinical trials have not confirmed the effect of BoNT-A for relieving myofascial pain in the neck, shoulders, or trunk [17,32].

Although BoNT-A has been widely used for muscular disorders, its role in treating CPPS has yet to be established. Present literature suggests that injecting BoNT-A into the PFMs may improve symptoms in women with CPPS. Joo et al. reported a 50\% success rate of BoNT-A injection in anismus for a long-term period [33]. Brin and Vapnek first reported the injection of BoNT-A to treat vaginismus in 1997 [34].

A systematic review including five studies supports that BoNT-A treatment was beneficial for relieving spasms of PFMs due to CPPS [17,35]. BoNT-A administration could relieve symptoms of dyspareunia, dysmenorrhea, non-menstrual pain and dyschezia. After BoNT-A treatment, it also improved the quality of life and sexual activity. The improvement may because of BoNT-A injection causing localized, partial denervation of the PFMs resulting in muscle weakness and reduction of pressure. 
CPP can occur at several muscles in the pelvic region such as pubococcygeus, ischiococcygeus, iliococcygeus, piriformis, transverse perinei muscles, and obturator internus. Preliminary studies have reported that BoNT-A injection could be able to decrease levator ani muscle spasms in women with CPP $[14,36,37]$. Halder et al. reported $200 \mathrm{U}$ of BoNT-A injections into the trigger points of the perineum in 50 women with CPP [38]. The outcomes showed a significant decrease in pelvic pain scores $(3.7 \pm 4.0$ vs. $6.4 \pm 1.8, p=0.005)$, and fewer trigger points $(44 \%$ vs. $100 \%, p<0.001)$. There was an improvement (20.7\%) in patients with the previous placement of incontinence sling versus no improvement $(0 \%)$ in pain $(p=0.003)$.

The major factor of pelvic pain in women with a spasm of PFMs appears to be ischemia due to vessel compression of the muscles, which leads to the release of bradykinin and sensitization or excitation of nociceptors [5]. BoNT-A injection can improve symptoms of CPP by the antispasticity effect on a spasm of PFMs rather than the result of the antinociceptive activity [17]. Injected BoNT-A into PFMs in women with CPP has been reported to improve the overall quality of life significantly, specifically to improve dyspareunia and female sexual function [30].

Because of the reversible effect and natural metabolism by the body, treatment with repeated BoNT-A injection for CPPS is frequently required. A low dosage of BoNT-A was injected in other muscle groups of the body at three-month intervals, as it was unlikely to produce significant side effects [14].

Injection of $300 \mathrm{U}$ of BoNT-A into PFMs may be safe, especially administered to the regions of hyper-spastic muscles [30]. However, the timing for repeat injection, the optimal dilution, and injected dosage are still challenging to maximize the therapeutic effects of BoNT-A in CPPS of women. It is unclear how significantly the pain will be relieved after BoNT-A injection. The outcome of BoNT-A in relieving CPPS needs more large prospective, randomized, controlled studies.

Table 1 lists important clinical studies of BoNT-A injection for relieving pain symptoms of PFMs. 
Table 1. Study of BoNT-A for pelvic floor muscle pain in CPPS women.

\begin{tabular}{|c|c|c|c|c|c|}
\hline Study & Javis [14] & Adelowo [36] & Nesbitt-Hawes [37] & Halder [38] & Morrissey [30] \\
\hline Numbers & 12 & 29 & $\begin{array}{l}37 \text { (single injection: } 26 \text {; multiple injection: } \\
\text { 11) }\end{array}$ & 50 & 21 \\
\hline Age & $31.1(18-55)$ & $55(38-62)$ & $\begin{array}{l}\text { Single injection: } 30 \\
\text { Multiple injection: } 31 \\
\text { (21-52 years) }\end{array}$ & 44.5 & $35.1(22-50)$ \\
\hline Study Model & Prospective cohort study & Retrospective cohort study & Prospective cohort study & Retrospective case series & Prospective pilot open-label study \\
\hline Follow-Up & 12 weeks & $\begin{array}{l}\text { Visit } 1:<6 \text { weeks post-injection } \\
\text { Visit 2: } \geq 6 \text { weeks post injection }\end{array}$ & 26 weeks & 6 weeks (2-192 weeks) & 6 months \\
\hline Criteria & $\begin{array}{l}\text { Objective hypertonicity of PFM and } \\
\text { 2-year history of CPP at least }\end{array}$ & $\begin{array}{l}\text { Refractory myofascial pelvic } \\
\text { pain }\end{array}$ & $\begin{array}{l}\text { Objective overactivity of PFM and a } \\
\text { two-year history of pelvic pain }\end{array}$ & $\begin{array}{l}\text { CPP, trigger points of pelvic } \\
\text { floor on examinations, and } \\
\text { failure (with subsequent } \\
\text { discontinuation) of one } \\
\text { treatment modality at least } \\
\text { including outpatient } \\
\text { physical treatment and/or } \\
\text { oral analgesics }\end{array}$ & $\begin{array}{l}\text { CPP and HTPFD who have failed } \\
\text { conventional therapy }\end{array}$ \\
\hline Dose of BoNT-A & $40 \mathrm{U}$ & $100-300 \mathrm{U}$ & $100 \mathrm{U}$ & - & Up to $300 \mathrm{U}$ \\
\hline Injection Sites & $\begin{array}{l}\text { Bilateral puborectalis and pubococcygeus } \\
\text { muscles }\end{array}$ & $\begin{array}{l}\text { PFMs (coccygeus, } \\
\text { iliococcygeus, pubococcygeus, } \\
\text { puborectalis, obturator, and } \\
\text { pyriformis muscles) }\end{array}$ & $\begin{array}{l}\text { Puborectalis and pubococcygeous } \\
\text { muscles }\end{array}$ & $\begin{array}{l}\text { Multiple areas of the } \\
\text { perineum }\end{array}$ & $\begin{array}{l}\text { Spastic PFM trigger points and deeper PFMs } \\
\text { (pubococcygeus, iliococcygeus, coccygeus, } \\
\text { and obturator internus muscles) }\end{array}$ \\
\hline Outcomes & $\begin{array}{l}\text { - Median VAS scores presented } \\
\text { improvements on dyspareunia ( } 80 \\
\text { vs. } 28, p=0.01) \text { and dysmenorrhea } \\
\text { (67 vs. } 28, p=0.03) \text {. } \\
\text { PFMs manometry showed a } 37 \% \\
\text { reduction in resting pressure at week } \\
4 \text { and a } 25 \% \text { reduction maintained at } \\
\text { week } 12(p<0.0001) \text {. } \\
\text { It showed significant improvements } \\
\text { of sexual activity scores, with a } \\
\text { reduction in discomfort ( } 4.8 \text { vs. } 2.2, \\
p=0.02) \text { and improvement in habit } \\
\text { (0.2 vs. } 1.9, p=0.03) \text {. }\end{array}$ & $\begin{array}{l}\text { - } 79.3 \% \text { improvement } \\
\text { in pain. } \\
\text { - } 51.7 \% \text { female patients } \\
\text { elected to have a second } \\
\text { BoNT-A injection. } \\
\text { - The median time of the } \\
\text { first injection to the } \\
\text { second injection was } 4.0 \\
\text { months (3.0-7.0 months). }\end{array}$ & $\begin{array}{l}\text { - } 26(70 \%) \text { women had one injection of } \\
\text { BoNT-A and } 11(30 \%) \text { had } 2 \text { or } \\
\text { more injections. } \\
\text { The median number of repeat } \\
\text { injections was } 3 \text {. } \\
\text { The second injection was performed } \\
\text { at the earliest at } 26 \text { weeks after the } \\
\text { first, with subsequent injections } \\
\text { having a median time to re-injection } \\
\text { of } 33.4 \text { weeks (range } 9.4-122.7 \\
\text { weeks). Single and repeated } \\
\text { injections both significantly reduced } \\
\text { dyspareunia by VAS scores (54 to } 30 \text {, } \\
\text { and } 51 \text { to } 23, p=0.001) \text {, } \\
\text { non-menstrual pelvic pain VAS ( } 37 \\
\text { to } 25, p=0.04) \text {, as well as vaginal } \\
\text { pressures ( } 40 \text { vs. } 34 \mathrm{~cm} \mathrm{H}_{2} \mathrm{O} \\
(p=0.02) \text {. }\end{array}$ & $\begin{array}{l}\text { Posttreatment, patients } \\
\text { had lower average } \\
\text { pelvic pain scores (6.4 } \\
\text { to } 3.7, p=0.005), \text { and } \\
\text { fewer trigger pints } \\
(44 \% \text { vs. } 100 \% \text {, } \\
p<0.001)\end{array}$ & $\begin{array}{l}\text { - } \quad 61.9 \% \text { improvement on GRA at } \\
4 \text { weeks. } \\
\text { - } 80.9 \% \text { improvement on GRA at } 8,12, \\
\text { and } 24 \text { weeks. } \\
\text { - Dyspareunia VAS significantly } \\
\text { improved at weeks } 12(5.6, p=0.011) \\
\text { and } 24(5.4, p=0.004) \text {. } \\
\text { - Sexual dysfunction as measured by the } \\
\text { FSDS significantly improved at } 8 \text { weeks } \\
(27.6, p=0.005), 12 \text { weeks }(27.9, \\
p=0.006) \text {, and } 24 \text { weeks }(22.6, p<0.001) \\
\text { compared with baseline }(34.5) \text {. } \\
\text { Vaginal manometry demonstrated a } \\
\text { significant decrease in resting pressures } \\
\text { and in maximum contraction pressures } \\
\text { at all follow-up visits }(p<0.05) .\end{array}$ \\
\hline
\end{tabular}

CPP: chronic pelvic pain. PFM: pelvic floor muscle. HTPFD: high-tone pelvic floor dysfunction GRA: global response assessment. FSDS: Female Sexual Distress Scale. 


\section{Clinical Application of BoNT-A in IC/BPS Women}

The etiology and pathophysiology of IC/BPS are still unclear. There are many treatments for relieving IC/BPS including analgesic medicine, changing habits of lifestyle, pentosan polysulfate sodium, cystoscopy with hydrodistention, or instillation of dimethyl sulfoxide in the bladder.

Smith et al. first reported that submucosal BoNT-A injection into 20 to 30 sites of the trigone and bladder floor for a total of 100 to $200 \mathrm{U}$ would result in a $69 \%$ improvement of IC/BPS patients, including daytime frequency episodes, nocturia, pain, and bladder capacity [39]. In 2009, Kuo et al. reported a prospective, randomized, and controlled study including 67 patients with IC/BPS who failed conventional treatments, comparing intravesical BoNT-A injection in $100 \mathrm{U}$ or $200 \mathrm{U}$ plus hydrodistention with hydrodistention alone. The IC/BPS symptom score significantly improved in all three groups. However, it only showed a significant reduction of pain visual analogue scale (VAS), an increase of functional bladder capacity (FBC) and cystometric bladder capacity in the BoNT-A group [40].

In 2016, a multicenter, randomized, double-blind, placebo-controlled trial compared hydrodistention plus $100 \mathrm{U}$ of BoNT-A injections at 20 sites with injections of normal saline at 20 sites in 60 patients with refractory IC/BPS. A significantly greater reduction of bladder pain symptoms and increased bladder capacity under cystoscopy were observed in the group with BoNT-A injection, with $63 \%$ of overall success rates versus $15 \%$ in the normal saline group [41].

Compared to single intravesical BoNT-A injection for IC/BPS patients, there were long-term therapeutic effects in repeated injections, such as pain relief, improved bladder capacity, and better success rates for a long-term period. Kuo et al. reported a repeated intravesical injection of $100 \mathrm{U}$ of BoNT-A every six months for up to four times or until symptoms improved in 81 patients with refractory IC/BPS. It showed significant improvement in pain relief, $\mathrm{FBC}$, and daytime frequency after repeated therapy with different BoNT-A injections. Compared to one single injection, it also reported significantly better success rates for four repeated injections $(p=0.0242)$ and three repeated injections $(p=0.050)$ [42]. In a recent prospective study, 104 patients received an intravesical injection of $100 \mathrm{U}$ of BoNT-A and cystoscopic hydrodistention for refractory IC/BPS. Repeated BoNT-A injections were done every six months for two years. The study showed that $56.7 \%$ of patients received four injections of BoNT-A and $34 \%$ of patients received another fifth injection because of progressive IC symptoms. It showed a better success rate in those patients who completed repeated BoNT-A injections and significant improvements of O'Leary-Sant IC symptom and problem indexes (ICSI, ICPI, OSS), painful VAS, FBC, frequency, and global response assessment (GRA) during 79 months of follow-up [43].

Liu et al. reported the levels of nerve growth factor (NGF) in the bladder tissue were significantly increased in 19 patients with IC/BPS compared with 12 healthy patients. After injections with $100 \mathrm{U}$ or $200 \mathrm{U}$ of BoNT-A followed by cystoscopic hydrodistention two weeks later, they showed a decrease of the NGF mRNA levels and no significant difference compared with the healthy controls [44]. Intravesical BoNT-A injections could improve chronic bladder inflammation, decrease apoptosis, and decrease the level of bladder vascular endothelial growth factor in patients with IC/BPS [45,46].

The injection sites and the numbers of injections are controversial. It has been reported to inject BoNT-A into the trigone and the posterior bladder wall simultaneously, only the trigone, and sites excluding out the trigone. Pinto et al. reported injecting $100 \mathrm{U}$ of BoNT-A into ten trigonal sites compared to saline injections for refractory IC/BPS patients. They showed significant improvements in bladder pain and quality of life [47]. Jiang et al. injected $100 \mathrm{U}$ of BoNT-A into 20 bladder body sites or 10 trigonal sites in 39 IC/BPS patients. After eight weeks from baseline, they showed no significant difference in changes in urinary frequency, voided volume, post-void residual volume, and bladder capacity. No significant difference in decreasing VAS, symptom improvement, and dysuria were also noted [48].

Kuo et al. investigated the therapeutic predictors, such as ICSI, ICPI, FBC, frequency, and first desire to void for successful treatment of BoNT-A injection in the bladder for refractory IC/BPS patients. Successful treatment was defined as GRA $\geq 2$ at six months. The success rate was $45.54 \%$ at six months. 
Multivariate logistic regression showed the only therapeutic predictor for successful management was the baseline ICSI. Patients with an ICSI $\geq 12$ may indicate a poorer therapeutic outcome of BoNT-A injections [49]. For refractory IC/BPS, the effectiveness and success of BoNT-A injections has been shown.

To summarize, BoNT-A injection has been widely studied for IC/BPS patients and it has become a promising treatment for refractory IC/BPS patients with the combination with hydrodistention (Table 2), although repeated injection may be needed for long-term therapeutic effects. 
Table 2. Study of BoNT-A for IC/BPS women.

\begin{tabular}{|c|c|c|c|c|c|c|c|c|}
\hline Reference & Study Design & Diagnosis & Numbers & Age & Follow-Up & BoNT-A Dose & Assessment & Outcomes \\
\hline Kuo HC [41] & $\begin{array}{l}\text { Multicenter, } \\
\text { randomized, } \\
\text { double-blind, } \\
\text { placebo-controlled } \\
\text { trial }\end{array}$ & $\begin{array}{l}\text { IC/BPS } \\
\text { refractory to } \\
\text { conventional } \\
\text { treatment }\end{array}$ & $\begin{array}{l}60 \text { (52 women, } \\
8 \mathrm{men})\end{array}$ & 50.8 & 8 weeks & $\begin{array}{l}\text { 100U (cystoscopic } \\
\text { hydrodistention plus } \\
\text { intravesical injections } \\
\text { of } 100 \mathrm{U} \text { BoNT-A) }\end{array}$ & $\begin{array}{l}\text { Pain VAS, } \\
\text { 3-day voiding } \\
\text { diary, } \\
\text { ICSI, } \\
\text { ICPI, } \\
\text { VUDS } \\
\text { GRA }\end{array}$ & $\begin{array}{l}-\quad \Delta \text { pain VAS of BoNT-A group vs. control group: }-2.6 \text { vs. }-0.9 \\
(p=0.021) \text {. } \\
\text { - } \quad 8 \text { weeks after BoNT-A injection, ICSI, ICPI, OSS, GRA, and } \\
\text { FBC all showed significant improvement in both groups. } \\
\text { At } 3 \text { months, GRA in BoNT-A group vs. saline group: } 62 \% \text { vs. } \\
15 \%(p=0.028) \text {. }\end{array}$ \\
\hline Kuo HC [42] & $\begin{array}{l}\text { Prospective } \\
\text { interventional } \\
\text { study }\end{array}$ & $\begin{array}{l}\text { IC/BPS } \\
\text { refractory to } \\
\text { conventional } \\
\text { treatment }\end{array}$ & $\begin{array}{l}81 \text { ( } 71 \text { women, } \\
10 \mathrm{men})\end{array}$ & $\begin{array}{l}\text { Women: 48; } \\
\text { Men } 48.2\end{array}$ & 24 months & $\begin{array}{l}100 \mathrm{U} \text { (injected into } \\
\text { bladder walls at } \\
\text { posterior and lateral } \\
\text { sites) followed by } \\
\text { cystoscopic } \\
\text { hydrondistention and } \\
\text { repeated injections } \\
\text { every } 6 \text { months up to } 4 \\
\text { times }\end{array}$ & $\begin{array}{l}\text { Pain VAS, } \\
\text { 3-day voiding } \\
\text { diary, } \\
\text { ICSI, } \\
\text { ICPI, } \\
\text { VUDS, } \\
\text { GRA }\end{array}$ & $\begin{array}{l}\text { - It showed significant improvement in ICSI, ICPI, VAS, FBC, } \\
\text { and daytime frequency after repeated treatment of BoNT-A } \\
\text { with different injections. } \\
\text { - It showed better success rates in patients with } 3(p=0.050) \\
\text { and } 4(p=0.0242) \text { repeated injections of BoNT-A, compared } \\
\text { to those with a single injection. } \\
\text { - Dysuria after each injection: } 30 \% \text {. } \\
\text { - } \quad \text { UTI after each injection: } 4.9-19 \% \text {. }\end{array}$ \\
\hline Lee CL [43] & Prospective study & $\begin{array}{l}\text { Refractory } \\
\text { IC/BPS }\end{array}$ & $\begin{array}{l}104 \text { ( } 88 \\
\text { women, } 16 \\
\text { men) }\end{array}$ & $\begin{array}{l}\text { Women: } 48.5 ; \\
\text { Men: } 46.6\end{array}$ & 79 months & $\begin{array}{l}100 \mathrm{U} \text { (delivered at } 20 \\
\text { suburothelial locations } \\
\text { at posterior and lateral } \\
\text { bladder walls) followed } \\
\text { by cystoscopic } \\
\text { hydrodistention and } \\
\text { repeated injections } \\
\text { every } 6 \text { months up to } 4 \\
\text { times or until } \\
\text { symptoms resolved }\end{array}$ & $\begin{array}{l}\text { Pain VAS, } \\
\text { 3-day voiding } \\
\text { diary, } \\
\text { ICSI, } \\
\text { ICPI, } \\
\text { VUDS, } \\
\text { GRA }\end{array}$ & $\begin{array}{l}\text { - At } 6 \text { months after one single injection, improvement of } \\
\text { symptoms include overall OSS }(23.7 \pm 6.1 \text { vs. } 16.6 \pm 8.9) \text {, pain } \\
\text { VAS }(5.2 \pm 2.4 \text { vs. } 3.5 \pm 2.5), \text { FBC }(129.1 \pm 75.0 \text { vs. } 177.7 \pm \\
\text { 85.0), daytime frequency episodes }(15.3 \pm 7.7 \text { vs. } 11.3 \pm 6.3) \text {, } \\
\text { and all of the } p \text { value }<0.0001 \text {. } \\
\text { - Improvement of GRA }(1.31 \pm 0.97, p<0.0001) \text {. } \\
\text { - After fourth injection of BoNT-A, OSS }(24.6 \pm 6.1 \text { vs. } 15.2 \pm \\
\text { 8.9), VAS (5.4 } \pm 2.2 \text { vs. } 2.9 \pm 2.3), \mathrm{FBC}(133.5 \pm 74.0 \text { vs. } 226.9 \pm \\
\text { 108.8), and daytime frequency }(15.2 \pm 7.1 \mathrm{vs.} 10.3 \pm 5.3) \text { all } \\
\text { showed improvement with } p \text { value }<0.0001 . \\
\text { - After each injection of BoNT-A, the most frequently reported } \\
\text { symptom is dysuria (32.7\% to } 11.7 \% \%) \text {. } \\
\text { - After each injection of BoNT-A, } 5.9 \% \text { to } 13.9 \% \text { of patients. } \\
\text { occurred urinary tract infection. }\end{array}$ \\
\hline Liu HT [44] & Prospective study & Refractory IC & $\begin{array}{l}19 \text { (14 women, } \\
5 \mathrm{men})\end{array}$ & $\begin{array}{l}\text { Women: } 37 \text {; } \\
\text { Men: } 41\end{array}$ & 3 months & $\begin{array}{l}100 \mathrm{U} \text { (14 patients) or } \\
200 \mathrm{U}(5 \text { patients) } \\
\text { followed by cystoscopic } \\
\text { hydrodistension } 2 \\
\text { weeks later }\end{array}$ & $\begin{array}{l}\text { Pain VAS, } \\
\text { 3-day voiding } \\
\text { diary, } \\
\text { VUDS }\end{array}$ & $\begin{array}{l}\text { - The FBC of the overall patients increased by } 1.4 \text { times the } \\
\text { baseline value. } \\
\text { - After BoNT-A treatment, the pain VAS score decreased from } \\
5.16 \pm 2.09 \text { to } 2.53 \pm 1.43(p<0.0001) \text {, and the daily frequency } \\
\text { episodes decreased from } 12.6 \pm 4.3 \text { to } 8.8 \pm 2.5 \text { ( } p=0.001) \text {. } \\
\text { - NGF mRNA levels at baseline: IC patients vs. control }=0.65 \pm \\
0.33 \text { vs. } 0.42 \pm 0.25, \mathrm{p}=0.046) \text {. } \\
\text { - At } 2 \text { weeks after BoNT-A injections, the levels of NGF mRNA } \\
\text { had decreased to } 0.47 \pm 0.23(p=0.002) \text {. } \\
\text { - The overall success rate: } 74 \% \text {. }\end{array}$ \\
\hline
\end{tabular}


Table 2. Cont.

\begin{tabular}{|c|c|c|c|c|c|c|c|c|}
\hline Reference & Study Design & Diagnosis & Numbers & Age & Follow-Up & BoNT-A Dose & Assessment & Outcomes \\
\hline Shie JH [45] & Prospective study & $\begin{array}{l}\text { IC/BPS and } \\
\text { glomerulations } \\
\text { after cystoscopic } \\
\text { hydrodistention }\end{array}$ & $\begin{array}{l}23 \text { women }(11 \\
\text { received three } \\
\text { repeated } \\
\text { injections } \\
\text { every } 6 \\
\text { months) }\end{array}$ & 46.6 & 18 months & $\begin{array}{l}100 \mathrm{U} \text { ( } 40 \text { suburothelial } \\
\text { injections at the lateral } \\
\text { and posterior bladder } \\
\text { walls) followed by } \\
\text { cystoscopic } \\
\text { hydrodistention }\end{array}$ & $\begin{array}{l}\text { Pain VAS, } \\
\text { 3-day voiding } \\
\text { diary, } \\
\text { OSS, } \\
\text { UDS, } \\
\text { GRA }\end{array}$ & $\begin{array}{l}\text { - After single BoNT-A treatment, it showed improvements in } \\
\text { clinical symptoms, pain VAS, and daytime frequency. } \\
\text { - After single injection of BoNT-A, tryptase } \\
\text { decreased significantly. } \\
11 \text { patients who received three repeated injections of BoNT-A } \\
\text { showed significantly lower pain VAS (mean: } 5.8 \text { vs. } 3.03 \text {, } \\
p=0 \text { ), glomerulation degree (mean: } 1.8 \text { vs. } 1.2, p=0.026 \text { ) and } \\
\text { GRA (mean: } 0.3 \text { vs. } 1.2, p=0 \text { ). } \\
\text { - SNAP-25 decreased after repeated injections with BoNT-A. }\end{array}$ \\
\hline Peng CH [46] & Prospective study & $\begin{array}{l}\text { Refractory } \\
\text { IC/BPS }\end{array}$ & $\begin{array}{l}21 \text { ( } 20 \text { women, } \\
1 \text { man) }\end{array}$ & 44.8 & 24 weeks & $\begin{array}{l}100 \mathrm{U}(20 \text { suburothelial } \\
\text { injection at posterior } \\
\text { and lateral bladder } \\
\text { walls) with cystoscopic } \\
\text { hydrodistention and } \\
\text { repeated every } 6 \\
\text { months for } 4 \text { times }\end{array}$ & $\begin{array}{l}\text { Pain VAS, } \\
\text { 3-day voiding } \\
\text { diary, } \\
\text { OSS, } \\
\text { UDS, } \\
\text { GRA }\end{array}$ & $\begin{array}{l}\text { - After BoNT-A treatment, it showed significantly decreased in } \\
\text { OSS }(15.1 \pm 8.65 \text { vs. } 21.1 \pm 7.92, p=0.009) \text { and VAS }(3.0 \pm 2.92 \\
\text { vs. } 5.14 \pm 2.46, p=0.003) \text {. } \\
\text { Decreased VEGF level: after BoNT-A treatment vs. } \\
\text { baseline }=0.83 \pm 0.28 \text { vs. } 1.0 ; p=0.016 \text {. } \\
\text { After BoNT-A treatment, apoptotic cell count decreased from } \\
1.76 \pm 1.69 \text { to } 0.86 \pm 1.00(p=0.026) \text { and mast cell activity } \\
\text { decreased from } 5.82 \pm 4.97 \text { to } 1.81 \pm 2.29(p=0.009) \text {. }\end{array}$ \\
\hline Pinto RA [47] & $\begin{array}{l}\text { Single center, } \\
\text { randomized, } \\
\text { double-blind, } \\
\text { placebo } \\
\text { controlled, phase } \\
2 \text { study }\end{array}$ & IC/BPS & 19 women & 45.8 & 12 weeks & 100U (10 trigonal sites) & $\begin{array}{l}\text { Pain VAS, } \\
\text { 3-day voiding } \\
\text { diary, } \\
\text { OSS, } \\
\text { QoL score }\end{array}$ & $\begin{array}{l}\text { - At week } 12 \text { BoNT-A treatment, it showed significantly } \\
\text { reduced pain compared with saline }(-3.8 \pm 2.5 \text { vs. }-1.6 \pm 2.1 \text {, } \\
\mathrm{p}<0.05) \text {. } \\
\text { - The mean change in OSS from baseline to week } 12 \text { : BoNT-A } \\
\text { group vs. saline group }=-9 \pm 4.7 \text { vs. }-7.1 \pm 4.6, p<0.05) \text {. } \\
\text { Reductions in voiding frequency were observed at } \\
\text { BoNT-A group. }\end{array}$ \\
\hline Jiang YH [48] & $\begin{array}{l}\text { Single center, } \\
\text { randomized, } \\
\text { double-blind } \\
\text { study }\end{array}$ & $\begin{array}{l}\text { Refractory } \\
\text { IC/BPS for at } \\
\text { least } 6 \text { months }\end{array}$ & $\begin{array}{l}39 \text { women } \\
\text { (bladder body, } \\
\mathrm{n}=20 \text {; trigone, } \\
\mathrm{n}=19 \text { ) }\end{array}$ & $\begin{array}{l}53.9 \text { (bladder } \\
\text { body group), } \\
55.1 \text { (trigone } \\
\text { group) }\end{array}$ & 12 weeks & $\begin{array}{l}\text { 100U (comparative } \\
\text { group: } 20 \text { bladder body } \\
\text { sites at the posterior } \\
\text { and lateral walls; } \\
\text { treatment group: } 10 \\
\text { trigonal sites) followed } \\
\text { by cystoscopic } \\
\text { hydrodistention }\end{array}$ & $\begin{array}{l}\text { Pain VAS, } \\
\text { 3-day voiding } \\
\text { diary, } \\
\text { OSS, } \\
\text { VUDS, } \\
\text { GRA }\end{array}$ & $\begin{array}{l}\text { - After BoNT-A injections, thirteen }(65.0 \%) \text { patients in bladder } \\
\text { body group and } 10(52.6 \%) \text { patients in trigone group had } \\
\text { improvement of VAS more than } 2 \text { points }(p=0.43) \text {. } \\
\text { After BoNT-A treatment, nine }(45 \%) \text { patients in bladder body } \\
\text { group and } 10(52.6 \%) \text { patients in trigone group had GRA } \geq 2 \\
(p=0.63) \text { and dysuria }(p=0.52) .\end{array}$ \\
\hline Kuo YC [49] & Prospective study & $\begin{array}{l}\text { Refractory } \\
\text { IC/BPS }\end{array}$ & $\begin{array}{l}101(88 \\
\text { women, } 13 \\
\text { men) }\end{array}$ & $\begin{array}{l}48.45 \text { (Women: } \\
\text { 48.81; Men: } \\
\text { 46.0) }\end{array}$ & 6 months & $\begin{array}{l}100 \mathrm{U} \text { ( } 20 \text { suburothelial } \\
\text { injection at posterior } \\
\text { and lateral walls) } \\
\text { immediately followed } \\
\text { by cystoscopic } \\
\text { hydrodistention }\end{array}$ & $\begin{array}{l}\text { Pain VAS, } \\
\text { 3-day voiding } \\
\text { diary, } \\
\text { OSS, } \\
\text { ICSI, } \\
\text { ICPI, } \\
\text { VUDS, } \\
\text { GRA }\end{array}$ & $\begin{array}{l}\text { - Significant improvements observed in OSS, ICSI, ICPI, pain } \\
\text { VAS, FBC, daytime frequency, nocturia, GRA at } 3 \text { months } \\
\text { after BoNT injections, and these improvements could exist at } \\
6 \text { months. } \\
\text { Overall successful rate at } 6 \text { months: } 45.54 \% \text { (women: } 46.59 \% \text {; } \\
\text { men: } 38.46 \% \text { ). } \\
\text { Baseline ICSI score was the only significant predictor for a } \\
\text { therapeutic outcome (cutoff value of ICSI to predict treatment } \\
\text { failure: ICSI } \geq 12 \text { ). }\end{array}$ \\
\hline
\end{tabular}

GRA: global response assessment. VAS: visual analog scale. OSS: O'Leary-Sant symptom score. ICSI: O'Leary-Sant symptom indexes. ICPI: O'Leary-Sant problem indexes. UDS:

Urodynamic study. VUDS: videourodynamic study. FBC: functional bladder capacity. NGF: nerve growth factor. SNAP-25: 25-kD synaptosomal-associated protein. VEGF: vascular endothelial growth factor. QoL: quality of life. 


\section{Animal Evidence of BoNT-A for IC/BPS}

Although there is currently no definite animal model for CPPS, several chemical-induced cystitis animal models have been used to investigate the pathophysiology and develop a new treatment strategy for this disease. Lucioni et al. explored the effect of BoNT-A on the sensory neurotransmitters in chronic and acute injury models of the rat bladder by intraperitoneal injection of cyclophosphamide (CYP) and incubation of the bladder preparation with hydrochloric acid $(\mathrm{HCl})$. The study found that a greater release of neuropeptides substance P (SP) and CGRP caused by acute injury with $\mathrm{HCl}$ and suggested that there is a potential therapeutic effect of BoNT-A in the treatment of neurogenic inflammation of the bladder [50].

Cayan et al. used 41 female Sprague-Dawley rats with intravesical instillation of $\mathrm{HCl}$ monthly to induce chemical cystitis and maintain chronic inflammation. These rats injected with 2-3 units of BoNT-A into the bladder detrusor and saline as the control group. Urodynamic studies showed that BoNT-A treatments increase the maximum bladder capacity and bladder compliance compared to the control group at the beginning and end of the study. The histological examinations reported similar counts of mast cells and leukocyte infiltration in these two groups. In this animal model of chemical cystitis, injected BoNT-A into the bladder detrusor led to improvements in vesical function which may be an alternative, minimally invasive treatment compared to other surgical modalities for a chronic inflammatory condition to improve deteriorated bladder function [51].

Smith et al. demonstrated intraperitoneally injected $150 \mathrm{mg} / \mathrm{kg}$ CYP to induce chronic cystitis in female Sprague-Dawley rats. It showed an increase of voiding frequency and hyperactivity of bladder. Treatment with CYP or BoNT-A did not affect the release of ATP in resting urothelium. Injection of CYP led to hypoosmotic stimulation and an increase of ATP release in chronic cystitis. After BoNT-A treatment, hypoosmotic shock-induced ATP decreased significantly. Cystometry revealed that CYP injection increased non-voiding bladder contraction. BoNT-A instillation markedly reduced non-voiding contraction frequency that was induced by CYP injection. However, neither CYP nor BoNT-A nor a combination of CYP + BoNT-A had any effect on the contraction frequency of bladder voiding. Furthermore, intravesical instillation of BoNT-A did not affect the release of ATP from the serosal side, implying that its effects were confined to the urothelial side of the bladder preparation [52].

Vemulakonda et al. studied the inhibitory function of BoNT-A on afferent pathways of chronic inflammation in the bladder. Among four groups of female Sprague-Dawley rats, namely group 1: saline-treated, group 2: BoNT-A treated, group 3: CYP treated, group 4: BoNT-A and CYP treated, all animals received intravesical protamine sulfate (1\%), followed by intravesical BoNT-A or saline, and subsequently CYP or saline-injected intraperitoneally. Compared to saline controls, the study showed an increase of L6 and S1 c-fos immunoreactive cells after CYP treatment. BoNT-A/CYP treated group presented with a significant decrease of L6 and S1 c-fos immunoreactive cells compared with the CYP group. There was no significant difference in presentation between these two groups of saline and BoNT-A alone. Cystometrogram revealed that the increase of the non-voiding intercontractile interval in the BoNT-A/CYP group was more than 10-fold in CYP group. Conclusively, in a CYP animal model of chronic bladder inflammation, intravesical BoNT-A significantly inhibits the afferent neural response without impairing efferent bladder function [53]. Table 3 concludes the animal studies of applying BoNT-A for IC/BPS treatment. 
Table 3. Study of BoNT-A treatment for IC/BPS in the animal.

\begin{tabular}{|c|c|c|c|c|}
\hline Reference & Animal Numbers & Models & Dose of BoNT-A & Outcomes \\
\hline Lucioni [50] & $\begin{array}{l}18 \text { male } \\
\text { Sprague-Dawley } \\
\text { rats }(300-350 \mathrm{~g})\end{array}$ & $\begin{array}{l}\text { Intraperitoneal injection with CYP or } \\
\text { saline for 10-day }\end{array}$ & $\begin{array}{l}\text { Harvested } \\
\text { bladders were } \\
\text { incubated in } 10 \mathrm{U} \\
\text { BoNT-A for } 1 \mathrm{~h}\end{array}$ & $\begin{array}{l}\text { Neuropeptides SP in saline } \\
\text { group vs. CYP group: } 1060 \text { vs. } \\
605 \text { pg/g }(p<0.005) \\
\text { SP in CYP group: before BTX vs. } \\
\text { after BTX: } 1060 \text { vs. } 709 \text { pg/g } \\
(p<0.05)\end{array}$ \\
\hline \multirow{3}{*}{ Smith [52] } & \multirow{3}{*}{$\begin{array}{l}21 \text { female Sprague- } \\
\text { Dawley rats } \\
(200-250 \mathrm{~g})\end{array}$} & $\begin{array}{l}\text { Intravesical instillation and } \\
\text { intraperitoneal injection into four } \\
\text { groups ( } n=5-6 \text { per group): }\end{array}$ & \multirow{3}{*}{$\begin{array}{l}\text { Bladder was } \\
\text { instilled with } 1 \mathrm{~mL} \\
\text { of } 20 \mathrm{U} \text { BoNT-A for } \\
30 \mathrm{~min}\end{array}$} & \multirow{3}{*}{$\begin{array}{l}\text { BoNT-A instillation markedly } \\
\text { reduced bladder hyperactivity } \\
\text { induced by CYP by reducing } \\
\text { non-voiding contraction } \\
\text { frequency by } 91 \% \text {. }\end{array}$} \\
\hline & & $\begin{array}{ll}\text { (1) } & \text { Control (intravesical } \\
\text { saline/intraperitoneal saline) } \\
\text { (2) } \\
\text { BoNT-A (intravesical } \\
\text { BoNT-A/intraperitoneal saline) } \\
\text { (3) } \text { CYP (intravesical } \\
\text { saline/intraperitoneal CYP) }\end{array}$ & & \\
\hline & & $\begin{array}{l}\text { (4) CYP + BoNT-A (intravesical } \\
\text { BoNT-A/intraperitoneal CYP) }\end{array}$ & & \\
\hline Cayan [51] & $\begin{array}{l}41 \text { female } \\
\text { Sprague-Dawley } \\
\text { rats }(200-300 \mathrm{~g})\end{array}$ & $\begin{array}{l}\text { Intravesical instillation of } \mathrm{HCl}(0.2 \mathrm{~mL} \\
\text { of } 0.4 \mathrm{~N} \mathrm{HCl}) \text { induced chemical } \\
\text { cystitis }\end{array}$ & $\begin{array}{l}2-3 \mathrm{U}(0.2-0.3 \mathrm{~mL}) \\
\text { BoNT-A was } \\
\text { injected into the } \\
\text { detrusor at the } 3,6 \text {, } \\
9 \text { and } 12 \text { o'clock } \\
\text { positions (10-12 } \\
\text { sites) }\end{array}$ & $\begin{array}{l}\text { Increases in the maximum } \\
\text { bladder capacity and compliance } \\
\text { were significantly higher in the } \\
\text { BoNT-A group compared to the } \\
\text { control group ( } p=0.000 \text { and } \\
p=0.025) \text {. }\end{array}$ \\
\hline $\begin{array}{l}\text { Vemulakonda } \\
\text { [53] }\end{array}$ & $\begin{array}{l}24 \text { female } \\
\text { Sprague-Dawley } \\
\text { rats }(200-250 \mathrm{~g})\end{array}$ & $\begin{array}{l}\text { Intravesical instillation and } \\
\text { intraperitoneal injection into four } \\
\text { groups: } \\
\text { (1) Saline (intravesical } \\
\text { saline/intraperitoneal saline) } \\
\text { (2) BoNT-A (intravesical } \\
\text { BoNT-A/intraperitoneal saline) } \\
\text { (3) CYP (intravesical } \\
\text { saline/intraperitoneal CYP) } \\
\text { (4) CYP/BoNT-A (intravesical } \\
\text { BoNT-A/intraperitoneal CYP) }\end{array}$ & $\begin{array}{l}\text { Bladder was } \\
\text { instilled with } 20 \mathrm{U} \\
\text { BoNT-A for } 30 \mathrm{~min}\end{array}$ & $\begin{array}{l}\text { After CYP treated, expression of } \\
\text { c-fos increased significantly in } \\
\text { L6 and S1 }(78 \% \text { and } 107 \%) \\
\text { compared to saline control } \\
(p<0.001) \text {. } \\
\text { Compared to the CYP group, it } \\
\text { showed a significant decrease of } \\
\text { c-fos expression in L6 and S1 } \\
(50 \% \text { and } 52 \%) \text { in the } \\
\text { BoNT-A/CYP group ( } p<0.001) \text {. } \\
\text { Compared to CYP group, the } \\
\text { increase of nonvoiding } \\
\text { intercontractile interval was } \\
\text { more than } 10-\text { fold in } \\
\text { BoNT-A/CYP group }(p<0.01) .\end{array}$ \\
\hline
\end{tabular}

Cystitis of rats was induced by chronic CYP model that reported by Vizzard [54]. Intraperitoneal injection with CYP $(150 \mathrm{mg} / \mathrm{kg})$ was administered every third day to a total of three doses to achieve chronic inflammation. CYP: cyclophosphamide. HCl: hydrochloric acid. SP: substance P.

\section{Clinical Use of BoNT-A for Sexual Pain Syndrome}

Women with sexual pain disorders experience genital pain during sexual intercourse occurring at the periods including before, in the process, or after the sexual activity that involves the clitoris, vulva, vagina, and/or perineum, thus causing difficulty in sexual intercourse and personal distress. Dyspareunia is painful sexual intercourse, in which pain can occur over the external genitalia, inside the vagina or deeper pelvis due to numerous medical, physical, social, or psychological causes. Generally, the prevalence of dyspareunia was reported to affect between $8 \%-21.1 \%$ of women [55]. More sexual pain disorders were reported in female patients with CPP than women without CPP [1]. Morrissey et al. reported a prospective pilot open-label study of 21 women with CPP and refractory high-tone pelvic floor dysfunction (HTPFD) under needle electromyography (EMG) guidance with BoNT-A injections [30]. They prepared $300 \mathrm{U}$ of BoNT-A with nonpreserved saline in a 10-mL syringe and attached it to a $12.5 \mathrm{~cm}$ disposable monopolar EMG needle electrode. BoNT-A was injected into the spastic PFM trigger point (30 U), other deeper PFMs including pubococcygeus, iliococcygeus, and coccygeus (30 $\mathrm{U}$ each as needed), and obturator internus muscles (up to $60 \mathrm{U}$ into each side). Of these 21 female patients, $66.7 \%$ had vulvodynia. After treatment, the dyspareunia VAS score showed significant improvement at weeks $12(5.6, p=0.011)$ and $24(5.4, p=0.004)$ than baseline (7.8). The Female Sexual Distress Scale (FSDS) showed significant improvement of sexual function at 8 weeks $(27.6, p=0.005), 12$ weeks $(27.9, p=0.006)$, and 24 weeks $(22.6, p<0.001)$ compared with baseline 
(34.5). Resting pressures and maximum contraction pressures of the vagina as measured by vaginal manometry significantly decreased during all follow-up examinations $(p<0.05)$.

Vulvodynia is characterized as genital pain without clear etiology that may have resulted from sexual intercourse and causes sexual pain disorder. In the general population, the estimated prevalence of vulvodynia ranges from $10 \%$ to $28 \%$ in reproductive-aged women [56]. Aberrant increase in the number of nociceptors, which causes peripheral hypersensitivity, leads to intraepithelial neural hyperplasia and strong pain in the vestibule, which may be the cause of vulvodynia [12]. Approximately $7-8 \%$ of women have experienced vulvodynia by age 40 that limited sexual intercourse [57]. BoNT-A can inhibit the release of ACh from sympathetic neurons and parasympathetic neurons to relieve vulvodynia and improve dyspareunia. A retrospective study recruited seven women aged 28-61 years with intractable genital pain that was refractory to conventional treatment [58]. Twenty units of BoNT-A was injected into the pain sites including the vestibule, levator ani muscle and the perineal body. If the symptoms had not subsided totally, $40 \mathrm{U}$ of BoNT-A was injected repeatedly every two weeks. After BoNT-A injections, pain decreased or disappeared in all patients. The mean VAS score decreased to 1.4 from 8.3 before the treatment, with no recurrence. The study showed improvement of sexual life without significant pain or discomfort during or after sexual activity.

Hedebo et al. used BoNT-A to treat vulvodynia refractory to conventional treatment for at least six months [59]. The cohort consisted of 79 women and each received $100 \mathrm{U}$ of BoNT-A injections. The results showed significant improvements in dyspareunia (7.82 to 5.82, $p<0.01$ ), Negative Interference in Quality of Life (NIQL) $(7.88$ to $6.19, p<0.01)$ and the cotton swab test (6.81 to 5.50, $p<0.01$ ).

High doses of BoNT-A injection seem to have effectiveness in the treatment of vulvodynia related to sexual pain syndrome. A randomized, double-blind, three-arm, placebo-controlled study from June 2008 to September 2014 included 32 women aged 23-35 years with provoked vestibulodynia [60]. They subcutaneously injected BoNT-A $50 \mathrm{U}(\operatorname{arm~A}), 100 \mathrm{U}(\mathrm{arm} \mathrm{B})$ or saline ( $\mathrm{arm} \mathrm{C}$ ) into the dorsal vulvar vestibulum and evaluated pain scores after three months. They injected $100 \mathrm{U}$ of BoNT-A for persistently symptomatic women. At the 6-month visit, symptomatic patients received a second injection of BoNT-A $100 \mathrm{U}$ in arm C. The results showed no significant differences in pain between these three groups after three months from the initial injection. However, significant improvements were observed among all three arms using the von Frey filaments test. Exploratory analyses reported that repeat injections with $100 \mathrm{U}$ of BoNT-A over six months had a significant reduction of pain including VAS and von Frey filaments. Fifty-eight percent of patients assessable after repeat BoNT-A injections with $100 \mathrm{U}$ had symptom-free or $\geq 2$ points improvement of VAS score.

In 2016 Pelletier et al. evaluated in a prospective cohort study the long-term effectiveness of BoNT-A injection for more than two years in 19 women with provoked vestibulodynia [61]. Fifty units of BoNT-A were diluted in $1.0 \mathrm{~mL}$ saline solution followed by injection into bilateral bulbospongiosus muscles for a total dose of $100 \mathrm{U}$. After 24 months, 37\% of participants had no pain. After treatment, they showed significant improvements in the VAS, Dermatology Life Quality Index (DLQI) and Female Sexual Function Index (FSFI) scores at 24 months compared to baseline $(p<0.0001)$. Eighteen women $(95 \%)$ were able to have sexual intercourse after 24 months.

BoNT-A was successfully used in sexual pain syndrome and appeared to have long-term beneficial effects for sexual activity (Table 4). It is important to continue further research for investigating the novel treatments in the sexual pain syndrome of women. 
Table 4. Studies of BoNT-A injection for sexual pain syndrome in women.

\begin{tabular}{|c|c|c|c|c|c|c|c|}
\hline Paper & Study Model & Patients & Treatment & Injection Sites & Result Measures & Duration & Outcomes \\
\hline Yoon [58] & $\begin{array}{l}\text { Retrospective } \\
\text { study }\end{array}$ & 7 & $\begin{array}{l}\text { Dilution: } 20 \mathrm{U} \text { of BoNT-A } \\
\text { diluted in isotonic saline. } \\
\text { Dose: } 20 \text { to } 40 \text { U of BoNT-A }\end{array}$ & $\begin{array}{l}\text { Vestibule, levator } \\
\text { ani muscle, } \\
\text { perineal body }\end{array}$ & VAS & 4-24 months & $\begin{array}{l}\text { - After BoNT-A injections, it showed disappear of pain in } \\
\text { all patients. } \\
\text { - Two patients needed only one injection; the other five } \\
\text { patients received a 2nd injections } \\
\text { - VAS score improved from } 8.3 \text { to } 1.4 \text {, with no recurrence. } \\
\text { - Improvement of sexual activity without significant } \\
\text { discomfort during or after sexual intercourse. }\end{array}$ \\
\hline Hebedo [59] & $\begin{array}{c}\text { Prospective } \\
\text { study }\end{array}$ & 79 & $\begin{array}{c}\text { Dilution: } 100 \mathrm{U} \text { of BoNT-A } \\
\text { diluted into } 1 \mathrm{~mL} \text { isotonic } \\
\text { saline. } \\
\text { Dose: } 100 \mathrm{U} \text { of BoNT-A }\end{array}$ & $\begin{array}{l}\text { Bilaterally (50 } \\
\text { units each site) } \\
\text { and levator ani } \\
\text { pars pubo rectalis }\end{array}$ & $\begin{array}{c}\text { NRS } \\
\text { NIQL } \\
\text { Cotton swab test } \\
\text { Active vita } \\
\text { sexualis }\end{array}$ & 6 months & $\begin{array}{l}\text { - } \quad \text { Dyspareunia: } 7.81 \text { to } 5.82(p<0.01) \\
\text { - } \quad \text { Cotton swab test: } 7.81 \text { to } 5.50(p<0.01) \\
\text { - } \quad \text { Active Vitae Sexualis: no significances }(p=0.25)\end{array}$ \\
\hline Pelletier [61] & $\begin{array}{l}\text { Prospective } \\
\text { study }\end{array}$ & 19 & $\begin{array}{l}\text { Dilution: } 50 \mathrm{U} \text { of BoNT-A } \\
\text { diluted into } 1 \mathrm{~mL} \text { saline. } \\
\text { Dose: } 100 \mathrm{U} \text { of BoNT-A }\end{array}$ & $\begin{array}{c}\text { Bilateral } \\
\text { bulbospongiosus } \\
\text { muscles }\end{array}$ & $\begin{array}{l}\text { VAS } \\
\text { FSFI } \\
\text { DLQI }\end{array}$ & 24 months & 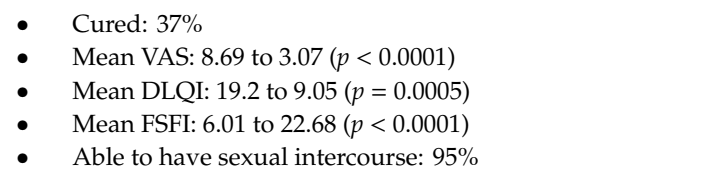 \\
\hline Diomande [60] & $\begin{array}{l}\text { Randomized, } \\
\text { double-blind, } \\
\text { placebo-controlled } \\
\quad \text { study }\end{array}$ & 32 & $\begin{array}{l}\text { • Dilution: } 50 \mathrm{U} \text { (arm A) or } \\
100 \text { U (arm B) of BoNT-A } \\
\text { diluted in } 1 \mathrm{~mL} \text { saline. } \\
\text { • Dose: } \\
\text { • Baseline: } \\
\text { Arm A: } 50 \mathrm{U} \\
\text { Arm B: } 100 \mathrm{U} \\
\text { Arm C: saline } \\
\text { • } 3 \text { month-visit: } \\
\text { Arm A \& B \& C: } 100 \mathrm{U} \text { (for } \\
\text { symptomatic patients) } \\
\text { • } 6 \text { month-visit: } \\
\text { Arm A \& B: - } \\
\text { Arm C: } 100 \mathrm{U} \text { (for } \\
\text { symptomatic patients) }\end{array}$ & $\begin{array}{l}\text { Subcutaneous } \\
\text { layers of the dorsal } \\
\text { vestibulum (each } \\
\text { side } 0.5 \mathrm{~mL} \text { ) }\end{array}$ & $\begin{array}{c}\text { Cotton } \\
\text { swab-provoked } \\
\text { VASVon Frey } \\
\text { filamentsMarinoff } \\
\text { dyspareunia scale }\end{array}$ & 6-9 months & $\begin{array}{l}\text { - Improvement of cotton swab provoked VAS score: no } \\
\text { significant difference between } 3 \text { groups and intragroup at } \\
3 \text { months. } \\
\text { - Improvement of von Frey filaments: significantly reduced } \\
\text { pain level in all treatment groups including placebo arm } \\
\text { after } 3 \text { months. } \\
\text { - It showed significant improvements of Marinoff } \\
\text { dyspareunia scale between baseline and } 3 \text { months in arm A } \\
\text { - Success rate ( } \geq 2 \text { VAS point improvement): } 58 \%\end{array}$ \\
\hline
\end{tabular}

NRS: Numerical rating scale. NIQL: Negative interference in quality of life. FSFI: Female Sexual Function Index. DLQI: Dermatology Life Quality Index. 


\section{Adverse Events of BoNT-A on CPPS}

The common adverse events of BoNT-A injection into the bladder for IC/BPS are slow urinary flow rate, decreased detrusor pressure, and dysuria $[39,62,63]$.

The most common adverse event of BoNT-A injection into PFMs for CPPS is dysuria. Increasing flatus has also been reported after BoNT-A injection into bilateral puborectalis and pubococcygeus muscles in women with chronic pelvic floor muscle spasms [14].

Adelowo et al. reported several adverse events, including retention of urine, fecal incontinence, constipation, and rectal pain after BoNT-A injection into PFMs (including coccygeus, iliococcygeus, pubococcygeus, puborectalis, obturator, and pyriformis muscles), which would be resolved spontaneously [36]. This might be because the injection sites were close to the sphincters of the urethra and anus.

Since the urethral sphincter and anal sphincter are adjacent to PFMs, BoNT-A injected into PFMs may result in disruption of urethral and/or anal sphincter mechanisms [30]. The adverse effects after BoNT-A injections reported progression of the following preexisting conditions: constipation $(28.6 \%)$, stress urinary incontinence $(4.8 \%)$, fecal incontinence $(4.8 \%)$, and new-onset stress urinary incontinence $(4.8 \%)$ [30]. Under electromyography (EMG) guidance, a needle provides more precise delivery of BoNT-A to highly spastic trigger points of the PFMs and helps with the avoidance of neighboring sphincter muscles [30].

Dressler et al. reported atrophy of target muscles after repeated injections of BoNT-A into a hyperactive muscle [64]. However, more serious side effects on systemic organs, such as respiratory failure, heart failure, weakness of muscles, or fatigue have not been reported [17].

Although most of the adverse events resulting from BoNT-A treatment are usually self-repairing, it should be clearly explained to the patient before BoNT-A injection. It is important to discuss with the patient the possibility of mild, transient, and reversible adverse effects on musculatures before BoNT-A injection.

There is still no guidelines about single injections or repeat injections, frequencies of repeat injections, an acceptable interval during repeat injections, injected sites and numbers, and maximum dosage of BoNT-A.

\section{Conclusions}

It is challenging to treat female CPPS patients because of the uncertainty of this disorder. There is currently no definite animal model for CPPS, although the chemical-induced cystitis rat model has been used to investigate the treatment strategy for this disease. Combination management, including physical therapy, biofeedback, behavioral modifications, and medicines may improve CPPS in women. Current literature suggests BoNT-A injection provides promising results in relieving symptoms of pelvic floor pain and muscle spasms in female patients. Intravesical injection of BoNT-A plus hydrodistension also helps to improve symptoms in refractory IC/BPS patients. BoNT-A injection appeared to have long-term beneficial effects for sexual activity in patients with sexual pain syndrome. It is safe for BoNT-A injection with limited adverse effects. However, more double-blind, randomized, controlled clinical studies and well-designed animal studies are needed to support the beneficial efficacy of BoNT-A injection in female patients with CPPS.

Author Contributions: C.-L.C. and E.M. wrote the paper; E.M. supervised and revised the paper. All authors have read and agreed to the published version of the manuscript.

Funding: This work was supported by Tri-Service General Hospital (grant No. TSGH-D-109067) to En Meng.

Conflicts of Interest: The authors declare no conflict of interest. 


\section{References}

1. Engeler, D.; Baranowski, A.P.; Berghmans, B.; Borovicka, J.; Cottrell, A.M.; Elneil, P.S.; Hughes, J.; Messelink, E.; de C Williams, A.C. EAU guidelines on chronic pelvic pain. 2019. Available online: https://uroweb.org/ guideline/chronic-pelvic-pain/ (accessed on 1 December 2019).

2. Ahangari, A. Prevalence of chronic pelvic pain among women: an updated review. Pain Physician 2014, 17, E141-E147. [PubMed]

3. Mathias, S.D.; Kuppermann, M.; Liberman, R.F.; Lipschutz, R.C.; Steege, J.F. Chronic pelvic pain: prevalence, health-Related quality of life, and economic correlates. Obstet. Gynecol. 1996, 87, 321-327. [CrossRef]

4. Speer, L.M.; Mushkbar, S.; Erbele, T. Chronic Pelvic Pain in Women. Am. Fam. Physician 2016, 93, 380-387.

5. Purwar, B.; Khullar, V. Use of botulinum toxin for chronic pelvic pain. Women's Health (Lond. Engl.) 2016, 12, 293-296. [CrossRef] [PubMed]

6. Williams, R.E.; Hartmann, K.E.; Sandler, R.S.; Miller, W.C.; Steege, J.F. Prevalence and characteristics of irritable bowel syndrome among women with chronic pelvic pain. Obstet. Gynecol. 2004, 104, 452-458. [CrossRef] [PubMed]

7. Haggerty, C.L.; Peipert, J.F.; Weitzen, S.; Hendrix, S.L.; Holley, R.L.; Nelson, D.B.; Randall, H.; Soper, D.E.; Wiesenfeld, H.C.; Ness, R.B. Predictors of chronic pelvic pain in an urban population of women with symptoms and signs of pelvic inflammatory disease. Sex. Transm. Dis. 2005, 32, 293-299. [CrossRef]

8. Latthe, P.; Mignini, L.; Gray, R.; Hills, R.; Khan, K. Factors predisposing women to chronic pelvic pain: Systematic review. BMJ (Clin. Res. ed.) 2006, 332, 749-755. [CrossRef]

9. Cheong, Y.C.; Smotra, G.; Williams, A.C. Non-Surgical interventions for the management of chronic pelvic pain. Cochrane Database Syst. Rev. 2014. [CrossRef]

10. Peck, M.W.; Smith, T.J.; Anniballi, F.; Austin, J.W.; Bano, L.; Bradshaw, M.; Cuervo, P.; Cheng, L.W.; Derman, Y.; Dorner, B.G.; et al. Historical Perspectives and Guidelines for Botulinum Neurotoxin Subtype Nomenclature. Toxins 2017, 9, 38. [CrossRef]

11. Moritz, M.S.; Tepp, W.H.; Bradshaw, M.; Johnson, E.A.; Pellett, S. Isolation and Characterization of the Novel Botulinum Neurotoxin A Subtype 6. mSphere 2018, 3. [CrossRef]

12. Moga, M.A.; Dimienescu, O.G.; Balan, A.; Scarneciu, I.; Barabas, B.; Ples, L. Therapeutic Approaches of Botulinum Toxin in Gynecology. Toxins 2018, 10, 169. [CrossRef] [PubMed]

13. Sloop, R.R.; Cole, B.A.; Escutin, R.O. Human response to botulinum toxin injection: type B compared with type A. Neurology 1997, 49, 189-194. [CrossRef] [PubMed]

14. Jarvis, S.K.; Abbott, J.A.; Lenart, M.B.; Steensma, A.; Vancaillie, T.G. Pilot study of botulinum toxin type A in the treatment of chronic pelvic pain associated with spasm of the levator ani muscles. Aust. N. Z. J. Obstet. Gynaecol. 2004, 44, 46-50. [CrossRef] [PubMed]

15. Stones, R.W.; Selfe, S.A.; Fransman, S.; Horn, S.A. Psychosocial and economic impact of chronic pelvic pain. Best Pract. Res. Clin. Obstet. Gynaecol. 2000, 14, 415-431. [CrossRef]

16. Erbguth, F.J. Historical notes on botulism, Clostridium botulinum, botulinum toxin, and the idea of the therapeutic use of the toxin. Mov. Disord. Off. J. Mov. Disord. Soc. 2004, 19 (Suppl. 8), S2-S6. [CrossRef]

17. Jhang, J.F.; Kuo, H.C. Novel Treatment of Chronic Bladder Pain Syndrome and Other Pelvic Pain Disorders by OnabotulinumtoxinA Injection. Toxins 2015, 7, 2232-2250. [CrossRef]

18. Montenegro, M.L.; Mateus-Vasconcelos, E.C.; Rosa e Silva, J.C.; Nogueira, A.A.; Dos Reis, F.J.; Poli Neto, O.B. Importance of pelvic muscle tenderness evaluation in women with chronic pelvic pain. Pain Med. (Malden, Mass.) 2010, 11, 224-228. [CrossRef]

19. Tu, F.F.; As-Sanie, S.; Steege, J.F. Prevalence of pelvic musculoskeletal disorders in a female chronic pelvic pain clinic. J. Reprod. Med. 2006, 51, 185-189.

20. Mense, S. Neurobiological basis for the use of botulinum toxin in pain therapy. J. Neurol. 2004, 251 (Suppl. 1), I1-I7. [CrossRef]

21. Kaya, S.; Hermans, L.; Willems, T.; Roussel, N.; Meeus, M. Central sensitization in urogynecological chronic pelvic pain: a systematic literature review. Pain Physician 2013, 16, 291-308.

22. Aoki, K.R. Evidence for antinociceptive activity of botulinum toxin type A in pain management. Headache 2003, 43 (Suppl. 1), S9-S15. [CrossRef] 
23. Foran, P.G.; Mohammed, N.; Lisk, G.O.; Nagwaney, S.; Lawrence, G.W.; Johnson, E.; Smith, L.; Aoki, K.R.; Dolly, J.O. Evaluation of the therapeutic usefulness of botulinum neurotoxin B, C1, E, and F compared with the long lasting type A. Basis for distinct durations of inhibition of exocytosis in central neurons. J. Biol. Chem. 2003, 278, 1363-1371. [CrossRef] [PubMed]

24. Durham, P.L.; Cady, R.; Cady, R. Regulation of calcitonin gene-Related peptide secretion from trigeminal nerve cells by botulinum toxin type A: implications for migraine therapy. Headache 2004, 44, 35-42. [CrossRef] [PubMed]

25. Khera, M.; Somogyi, G.T.; Kiss, S.; Boone, T.B.; Smith, C.P. Botulinum toxin A inhibits ATP release from bladder urothelium after chronic spinal cord injury. Neurochem. Int. 2004, 45, 987-993. [CrossRef] [PubMed]

26. Arezzo, J.C. Possible mechanisms for the effects of botulinum toxin on pain. Clin. J. Pain 2002, 18, S125-S132. [CrossRef] [PubMed]

27. Liu, B.L.; Yang, F.; Zhan, H.L.; Feng, Z.Y.; Zhang, Z.G.; Li, W.B.; Zhou, X.F. Increased severity of inflammation correlates with elevated expression of TRPV1 nerve fibers and nerve growth factor on interstitial cystitis/bladder pain syndrome. Urol. Int. 2014, 92, 202-208. [CrossRef] [PubMed]

28. Tempest, H.V.; Dixon, A.K.; Turner, W.H.; Elneil, S.; Sellers, L.A.; Ferguson, D.R. P2X and P2X receptor expression in human bladder urothelium and changes in interstitial cystitis. BJU Int. 2004, 93, 1344-1348. [CrossRef]

29. Xiao, L.; Cheng, J.; Dai, J.; Zhang, D. Botulinum toxin decreases hyperalgesia and inhibits P $2 \times 3$ receptor over-Expression in sensory neurons induced by ventral root transection in rats. Pain Med. (Malden, Mass.) 2011, 12, 1385-1394. [CrossRef]

30. Morrissey, D.; El-Khawand, D.; Ginzburg, N.; Wehbe, S.; O’Hare, P., 3rd; Whitmore, K. Botulinum Toxin A Injections Into Pelvic Floor Muscles Under Electromyographic Guidance for Women With Refractory High-Tone Pelvic Floor Dysfunction: A 6-Month Prospective Pilot Study. Female Pelvic Med. Reconstr. Surg. 2015, 21, 277-282. [CrossRef]

31. Scott, A.B.; Rosenbaum, A.; Collins, C.C. Pharmacologic weakening of extraocular muscles. Investig. Ophthalmol. 1973, 12, 924-927.

32. Ho, K.Y.; Tan, K.H. Botulinum toxin A for myofascial trigger point injection: A qualitative systematic review. Eur. J. Pain (Lond. Engl.) 2007, 11, 519-527. [CrossRef] [PubMed]

33. Joo, J.S.; Agachan, F.; Wolff, B.; Nogueras, J.J.; Wexner, S.D. Initial North American experience with botulinum toxin type A for treatment of anismus. Dis. Colon Rectum 1996, 39, 1107-1111. [CrossRef] [PubMed]

34. Brin, M.F.; Vapnek, J.M. Treatment of vaginismus with botulinum toxin injections. Lancet (Lond. Engl.) 1997, 349, 252-253. [CrossRef]

35. Bhide, A.A.; Puccini, F.; Khullar, V.; Elneil, S.; Digesu, G.A. Botulinum neurotoxin type A injection of the pelvic floor muscle in pain due to spasticity: A review of the current literature. Int. Urogynecol. J. 2013, 24, 1429-1434. [CrossRef]

36. Adelowo, A.; Hacker, M.R.; Shapiro, A.; Modest, A.M.; Elkadry, E. Botulinum toxin type A (BOTOX) for refractory myofascial pelvic pain. Female Pelvic Med. Reconstr. Surg. 2013, 19, 288-292. [CrossRef]

37. Nesbitt-Hawes, E.M.; Won, H.; Jarvis, S.K.; Lyons, S.D.; Vancaillie, T.G.; Abbott, J.A. Improvement in pelvic pain with botulinum toxin type A-Single vs. repeat injections. Toxicon Off. J. Int. Soc. Toxinol. 2013, 63, 83-87. [CrossRef]

38. Halder, G.E.; Scott, L.; Wyman, A.; Mora, N.; Miladinovic, B.; Bassaly, R.; Hoyte, L. Botox combined with myofascial release physical therapy as a treatment for myofascial pelvic pain. Investig. Clin. Urol. 2017, 58, 134-139. [CrossRef]

39. Smith, C.P.; Radziszewski, P.; Borkowski, A.; Somogyi, G.T.; Boone, T.B.; Chancellor, M.B. Botulinum toxin a has antinociceptive effects in treating interstitial cystitis. Urology 2004, 64, 871-875. [CrossRef]

40. Kuo, H.C.; Chancellor, M.B. Comparison of intravesical botulinum toxin type A injections plus hydrodistention with hydrodistention alone for the treatment of refractory interstitial cystitis/painful bladder syndrome. BJU Int. 2009, 104, 657-661. [CrossRef]

41. Kuo, H.C.; Jiang, Y.H.; Tsai, Y.C.; Kuo, Y.C. Intravesical botulinum toxin-A injections reduce bladder pain of interstitial cystitis/bladder pain syndrome refractory to conventional treatment-A prospective, multicenter, randomized, double-blind, placebo-controlled clinical trial. Neurourol. Urodyn. 2016, 35, 609-614. [CrossRef]

42. Kuo, H.C. Repeated onabotulinumtoxin-A injections provide better results than single injection in treatment of painful bladder syndrome. Pain Physician 2013, 16, E15-E23. [PubMed] 
43. Lee, C.L.; Kuo, H.C. Long-Term Efficacy and Safety of Repeated Intravescial OnabotulinumtoxinA Injections Plus Hydrodistention in the Treatment of Interstitial Cystitis/Bladder Pain Syndrome. Toxins 2015, 7, 4283-4293. [CrossRef] [PubMed]

44. Liu, H.T.; Kuo, H.C. Intravesical botulinum toxin A injections plus hydrodistension can reduce nerve growth factor production and control bladder pain in interstitial cystitis. Urology 2007, 70, 463-468. [CrossRef] [PubMed]

45. Shie, J.H.; Liu, H.T.; Wang, Y.S.; Kuo, H.C. Immunohistochemical evidence suggests repeated intravesical application of botulinum toxin A injections may improve treatment efficacy of interstitial cystitis/bladder pain syndrome. BJU Int. 2013, 111, 638-646. [CrossRef]

46. Peng, C.H.; Jhang, J.F.; Shie, J.H.; Kuo, H.C. Down regulation of vascular endothelial growth factor is associated with decreased inflammation after intravesical OnabotulinumtoxinA injections combined with hydrodistention for patients with interstitial cystitis-Clinical results and immunohistochemistry analysis. Urology 2013, 82, e1451-e1456. [CrossRef]

47. Pinto, R.A.; Costa, D.; Morgado, A.; Pereira, P.; Charrua, A.; Silva, J.; Cruz, F. Intratrigonal OnabotulinumtoxinA Improves Bladder Symptoms and Quality of Life in Patients with Bladder Pain Syndrome/Interstitial Cystitis: A Pilot, Single Center, Randomized, Double-Blind, Placebo Controlled Trial. J. Urol. 2018, 199, 998-1003. [CrossRef]

48. Jiang, Y.H.; Jhang, J.F.; Lee, C.L.; Kuo, H.C. Comparative study of efficacy and safety between bladder body and trigonal intravesical onabotulinumtoxina injection in the treatment of interstitial cystitis refractory to conventional treatment-A prospective, randomized, clinical trial. Neurourol. Urodyn. 2018, 37, 1467-1473. [CrossRef]

49. Kuo, Y.C.; Kuo, H.C. O'Leary-Sant Symptom Index Predicts the Treatment Outcome for OnabotulinumtoxinA Injections for Refractory Interstitial Cystitis/Bladder Pain Syndrome. Toxins 2015, 7, 2860-2871. [CrossRef]

50. Lucioni, A.; Bales, G.T.; Lotan, T.L.; McGehee, D.S.; Cook, S.P.; Rapp, D.E. Botulinum toxin type A inhibits sensory neuropeptide release in rat bladder models of acute injury and chronic inflammation. BJU Int. 2008, 101, 366-370. [CrossRef]

51. Cayan, S.; Coskun, B.; Bozlu, M.; Acar, D.; Akbay, E.; Ulusoy, E. Botulinum toxin type A may improve bladder function in a rat chemical cystitis model. Urol. Res. 2003, 30, 399-404. [CrossRef]

52. Smith, C.P.; Vemulakonda, V.M.; Kiss, S.; Boone, T.B.; Somogyi, G.T. Enhanced ATP release from rat bladder urothelium during chronic bladder inflammation: effect of botulinum toxin A. Neurochem. Int. 2005, 47, 291-297. [CrossRef] [PubMed]

53. Vemulakonda, V.M.; Somogyi, G.T.; Kiss, S.; Salas, N.A.; Boone, T.B.; Smith, C.P. Inhibitory effect of intravesically applied botulinum toxin A in chronic bladder inflammation. J. Urol. 2005, 173, 621-624. [CrossRef] [PubMed]

54. Vizzard, M.A. Alterations in neuropeptide expression in lumbosacral bladder pathways following chronic cystitis. J. Chem. Neuroanat. 2001, 21, 125-138. [CrossRef]

55. Latthe, P.; Latthe, M.; Say, L.; Gulmezoglu, M.; Khan, K.S. WHO systematic review of prevalence of chronic pelvic pain: a neglected reproductive health morbidity. BMC Public Health 2006, 6, 177. [CrossRef]

56. Sorensen, J.; Bautista, K.E.; Lamvu, G.; Feranec, J. Evaluation and Treatment of Female Sexual Pain: A Clinical Review. Cureus 2018, 10, e2379. [CrossRef]

57. Harlow, B.L.; Kunitz, C.G.; Nguyen, R.H.; Rydell, S.A.; Turner, R.M.; MacLehose, R.F. Prevalence of symptoms consistent with a diagnosis of vulvodynia: population-Based estimates from 2 geographic regions. Am. J. Obstet. Gynecol. 2014, 210, 40.e41-e48. [CrossRef]

58. Yoon, H.; Chung, W.S.; Shim, B.S. Botulinum toxin A for the management of vulvodynia. Int. J. Impot. Res. 2007, 19, 84-87. [CrossRef]

59. Hedebo Hansen, T.; Guldberg, R.; Meinert, M. Botulinum toxin-Treatment of localized provoked vulvodynia refractory to conventional treatment. Eur. J. Obstet. Gynecol. Reprod. Biol. 2019, 234, 6-9. [CrossRef]

60. Diomande, I.; Gabriel, N.; Kashiwagi, M.; Ghisu, G.P.; Welter, J.; Fink, D.; Fehr, M.K.; Betschart, C. Subcutaneous botulinum toxin type A injections for provoked vestibulodynia: A randomized placebo-Controlled trial and exploratory subanalysis. Arch Gynecol. Obstet. 2019, 299, 993-1000. [CrossRef]

61. Pelletier, F.; Girardin, M.; Humbert, P.; Puyraveau, M.; Aubin, F.; Parratte, B. Long-Term assessment of effectiveness and quality of life of OnabotulinumtoxinA injections in provoked vestibulodynia. J. Eur. Acad. Dermatol. Venereol. JEADV 2016, 30, 106-111. [CrossRef] 
62. Chung, S.D.; Kuo, Y.C.; Kuo, H.C. Intravesical onabotulinumtoxinA injections for refractory painful bladder syndrome. Pain Physician 2012, 15, 197-202. [PubMed]

63. Giannantoni, A.; Porena, M.; Costantini, E.; Zucchi, A.; Mearini, L.; Mearini, E. Botulinum A toxin intravesical injection in patients with painful bladder syndrome: 1-Year followup. J. Urol. 2008, 179, 1031-1034. [CrossRef] [PubMed]

64. Dressler, D.; Adib Saberi, F. Botulinum toxin: Mechanisms of action. Eur. Neurol. 2005, 53, 3-9. [CrossRef] [PubMed]

(C) 2020 by the authors. Licensee MDPI, Basel, Switzerland. This article is an open access article distributed under the terms and conditions of the Creative Commons Attribution (CC BY) license (http://creativecommons.org/licenses/by/4.0/). 